ORIGINAL PAPER

\title{
Extracellular polysaccharides are involved in the attachment of Azospirillum brasilense and Rhizobium leguminosarum to arbuscular mycorrhizal struc- tures
}

\author{
V. Bianciotto ${ }^{1}$, S. Andreotti ${ }^{2}$, R. Balestrini ${ }^{1}$, P. Bonfante ${ }^{1,2}$ and S. Perotto ${ }^{1}$
}

${ }^{1}$ Centro di Studio sulla Micologia del Terreno-CNR and ${ }^{2}$ Dipartimento di Biologia Vegetale dell'Università, V.le Mattioli 25, 10125 Torino, Italy

Keywords: PGPRs, rhizosphere, mycorrhizal fungi, extracellular polysaccharides, biofilm

\section{SUMMARY}

Arbuscular mycorrhizal (AM) fungi, one of the most important component of the soil microbial community, establish physical interactions with naturally occurring and genetically modified bacterial biofertilizers and biopesticides, commonly referred to as plant growth-promoting rhizobacteria (PGPR). We have used a genetic approach to investigate the bacterial components possibly involved in the attachment of two PGPR (Azospirillum and Rhizobium) to AM roots and AM fungal structures. Mutants affected in extracellular polysaccharides (EPS) have been tested in in vitro adhesion assays and shown to be strongly impaired in the attachment to both types of surfaces as well as to quartz fibers. Anchoring of rhizobacteria to AM fungal structures may have special ecological and biotechnological significance because it may facilitate colonisation of new rhizospheres by the bacteria, and may be an essential trait for the development of mixed inocula.

\section{INTRODUCTION}

The rhizosphere is a dynamic soil compartment in which microbes take advantage of the organic mat- ter released by the plant root (Lynch 1990). In this compartment, microorganisms that can be either beneficial or detrimental to plants interact with each other in synergistic and antagonistic ways. Among the beneficial microorganisms, mycorrhizal fungi are the most universal plant root associates, as they form symbiosis with more than 95\% of land plants (Smith and Read 1997). Arbuscular mycorrhizal (AM) fungi, the most widespread in agricultural and natural soils, improve plant nutrition and plant health through increased protection against abiotic and biotic stresses (Bethlenfalvay and Linderman 1992). Several beneficial bacteria also associate with the plant root surface and are collectively termed plant growth-promoting rhizobacteria (PGPR). Their beneficial effect on plants is based on different mechanisms such as improved mineral nutrition, disease suppression and increased growth through the production of phytohormons production (Weller 1988; Kloepper et al., 1991; Lugtenberg et al., 1991; Défago and Keel 1995). Effectiveness of PGPR depends on their ability to colonize the root surface, a process involving several bacterial components such as motility, adhesive surface molecules and rhizosphere competence (Lugtenberg and Dekkers 1999). 
Increasing attention is focussed on the synergistic and antagonistic interactions between PGPR bacteria and mycorrhizal fungi, in particular AM fungi (Barea 1997). For example, colonization of sugar cane by PGPRs is increased when AM fungi are present in mixed inocula (Boddey et al., 1991). A possible explanation given by these authors is that AM fungi may act as a vehicle to spread PGPR to neighbouring rhizospheres. The observation of bacterial adhesion to AM fungal spores and hyphal structures, demonstrated in vitro for a variety of PGPR strains (Bianciotto et al., 1996) would support this hypothesis. Bacterial attachment seems to be a general trait in the interactions between rhizosphere bacteria and mycorrhizal fungi, as it was also demonstrated for ectomycorrhizal fungi (Garbaye 1994; Nurmiaho-Lassila et al. 1997).

Little is known on the molecular bases of PGPR attachment onto mycorrhizal fungi. By contrast, a large set of experiments has demonstrated the role of several surface components in the physical interactions between beneficial or detrimental rhizosphere bacteria and the plant root. Bacteria attachment generally proceeds through two consecutive steps (Vande Broek and Vanderleyden 1995). In the first step, the bacteria adhere loosely as single cells, whereas in the second step the bacteria become more firmly attached to the plant root and additional free bacteria are entrapped, resulting in the formation of large bacterial clusters at the attachment site. These two consecutive steps have also been described in the colonisation of inert solid substrates, where bacteria eventually assemble into complex clusters termed biofilms (Costerton et al., 1995).

Appendages such as pili, fimbriae and flagella are involved in the initial attachment of bacteria to solid surfaces and their role has been demonstrated for a number of pathogenic and beneficial plant/microbe interactions (see Vande Broek and Vanderleyden 1995). In particular, the adhesive protein richadesin is held responsible of the first attachment step of $R$. leguminosarum to plant cells (Smit et al., 1989). In A. brasilense, a component located on the polar flagellum is involved in adhesion as mutants lacking polar flagella are strongly impaired in adsorption to the root (Croes et al., 1993).

During the second step, extracellular polysaccharides are responsible of the firm anchoring of bacteria to the plant surface, and various polymers have been identified in different plant/bacterial combinations. Cellulose fibrils have been identified at the attachment site of $R$. leguminosarum (Smit et al., 1992) to the plant cell wall. The involvement of calcofluor-binding surface polysaccharides in the anchoring of $A$. brasilense to plant cells has been demonstrated by Michiels et al. (1991), since mutants impaired in their production showed 6 to 15 -fold reduced anchoring capacity. However, extracellular polysaccharides could not be detected at the attachment site of $A$. brasilense to glass and polystirene after 24h of contact (Dufrêne et al., 1996), indicating that attachment of rhizosphere bacteria to solid substrates is a complex phenomenon that requires further investigations. Some of the surface characteristics of $A$. brasilense relevant to cell aggregation and attachment to plant roots have been recently reviewed by Burdman et al. (2000).

To understand the role of different surface components in the attachment of PGPRs to AM fungal structures and mycorrhizal roots, we have tested in an in vitro assay mutants of $A$. brasilense and $R$. leguminosarum impaired in the production of extracellular polysaccharides. The results demonstrate that they play a crucial role in the anchoring of bacteria and in the formation of biofilms on the root and the AM fungus.

\section{MATERIAL AND METHODS}

\section{Fungal material}

Sterilized seeds of Trifolium repens L. (clover) were sown in sterilized quartz sand. Mycorrhizal plants were obtained by injecting a sterilized suspension of spores of Gigaspora margarita Becker \& Hall isolate BEG 34) around the seedlings. Spores of G. margarita recoverd from pot cultures of clover by wet sieving (Gerdemann 1963) were surface sterilized with $4 \%$ Chloramine $\mathrm{T}$ and 300 ppm streptomycin for $30 \mathrm{~min}$, rinsed 5 times over $1 \mathrm{~h}$ with sterile distilled water and left to germinate in distilled water in petri dishes $(30$ spores per plate) at $30^{\circ} \mathrm{C}$ in the dark. $70-80 \%$ germination was obtained within 10 days.

\section{The transformed carrot root system}

For the assay, non mycorrhizal transformed carrot (Daucus carota) hairy roots and hairy roots colonized with Glomus intraradices Schenck \& 
Smith were cultured in minimal (M) medium (Bécard and Fortin 1988). Cultures were originally set up with soil-isolated spores, as described by Chabot et al. (1992). Subculturing of mycorrhizal roots was performed every 2 to 3 months by transferring colonized root pieces to fresh solid $\mathrm{M}$ medium (Bécard and Fortin 1988). Petri dishes were kept in the dark at $26 \pm 1^{\circ} \mathrm{C}$.

\section{Bacterial strains and adhesion assay}

The bacterial strains and their characteristics are illustrated in Table I. EPS mutants of A. brasilense were identified for their reduced or negative staining with the fluorescent dye calcofluor (Michielis et al., 1991). For $R$. leguminosarum, the mutant EPS phenotype was assessed by colony morphology (Zorreguieta et al., 2000)

The bacterial strains were grown in Luria-Bertani (Azospirillum) or in Tryptone-Yeast (Rhizobium) liquid medium overnight at $28^{\circ} \mathrm{C}$ with gentle shaking. The bacterial cell suspensions were spun at $3000 \mathrm{~g}$ for $20 \mathrm{~min}$, the surnatant was discarded and the pellet resuspended in $15 \mathrm{ml}$ phosphate buffer (50 $\mathrm{mM}) \mathrm{pH}$ 7.2. The concentration of bacterial cells was adjusted to $10^{7}-10^{8} \mathrm{CFU} / \mathrm{ml}$. Fungal and root samples were transferred to a petri plate, submerged in the bacterial cell suspension and maintained for $16 \mathrm{~h}$ at RT with gentle rocking. After washing with five changes of fresh phosphate buffer over $30 \mathrm{~min}$ on an orbital shaker, samples were prepared for observation by confocal microscopy and transmis- sion electron microscopy. Parallel control samples were incubated only in buffer to check that no bacterial contamination occurred. Attachment to inorganic substances, such us quartz fibres, was also tested following the same protocol.

\section{Confocal microscopy}

After the assay, unfixed geminated spores of $G$. margarita, as well as mycorrhizal and non mycorrhizal carrot roots, were stained with the Live/Dead Bac Light $^{\mathrm{TM}}$ Bacteria Viability Kit (Molecular Probes) at room temperature in the dark for $15 \mathrm{~min}$, according to the manufacturer's instructions. This kit contains a proprietary mixture of nucleic acid stains that distinguish between live bacteria, which fluoresce green under blue light $(488 \mathrm{~nm})$, from dead bacteria fluorescing red under green light $(514 \mathrm{~nm})$. No fixing or washing steps were used. The samples were mounted in an antifading mounting (Citifluor) and observed under a Nikon Optiphot-2 Microscope with a View Scan DVC-250 Confocal system (Biorad, Hemel Hempstead, UK).

To rule out the possibility that fungal and roots surfaces were already contaminated by other bacteria, germinated spores of G. margarita and mycorrhizal carrot roots stained with the Live/Dead BacLight ${ }^{\mathrm{TM}}$ Bacteria Viability Kit were observed by fluorescence microscopy without prior incubation with bacteria. The same control sample was run in parallel to all adhesion experiments.

Table I

Bacterial strains used in this study

\begin{tabular}{cclcc}
\hline Species & Strain & Relevant genetic features & Phenotype* & Reference \\
\hline A. brasilense & Sp7 & & WT & Tarrand et al. 1978 \\
& 7030 & Sm resistant mutant of Sp7 & WT & Michielis et al. 1991 \\
& AB7001 & Sp7exoC::Tn5 & EPS & Michielis et al. 1988 \\
& AB7002 & Sp7exoB1::Tn5 & EPS $^{\text {r }}$ & Michielis et al. 1988 \\
& & $7030:: T n 5-23$ & EPS & Michielis et al. 1990 \\
& & EPS & This work \\
\hline R. leguminosarum & B556 & 8401pRL1JI & WT & Sindhu et al. 1990 \\
& A507 & 8401pRL1JIpss5::Tn5 & EPS & Zorreguieta et al. 2000 \\
& A517 & 8401pRL1JIpss6::Tn5 & EPS & Zorreguieta et al. 2000 \\
\hline
\end{tabular}

*WT: Wild type

EPS ${ }^{r}$ : EPS reduced

EPS $^{-}$: EPS deficien 


\section{Electron microscopy}

Carrot transformed roots segments were fixed in $2.5 \%(\mathrm{v} / \mathrm{v})$ glutaraldehyde in $10 \mathrm{mM}$ Na-phosphate buffer ( $\mathrm{pH} 7.2$ ) for $2 \mathrm{~h}$ at $4^{\circ} \mathrm{C}$. After rinsing with the same buffer, samples were postfixed in $1 \%(\mathrm{w} / \mathrm{v})$ $\mathrm{OsO}_{4}$ in double distilled $\mathrm{H}_{2} 0$ for $1 \mathrm{~h}$, washed three times with double distilled water and dehydrated in an ethanol series (30, 50, 70, 90 100\%; 10 min each step) at room temperature. The root segments were infiltrated in 2:1 (v/v) ethanol:LR White resin (Polysciences Inc., Warrington, PA, USA) for $1 \mathrm{~h}$ 1:2 (v/v) ethanol:LR White for $2 \mathrm{~h}$ and $100 \% \mathrm{LR}$ White overnight at $4^{\circ} \mathrm{C}$ according to Moore et al (1991). Semi-thin sections (1um) were cut from 510 root embedded samples for each bacterial population in the presence and in the absence of the fungus. Sections were stained with $1 \%$ toluidine blue for morphological observations.

\section{RESULTS}

Attachment of Azospirillum brasilense and Rhizobium leguminosarum to Gigaspora margarita germinated in vitro

All bacterial strains listed in Table I were tested in adhesion assays on fungal structures of Gi. margarita axenically germinated in vitro and the results are summarized in Table II. The wild type Sp7 strain of A. brasilense and the wild type strain of $R$. leguminosarum formed a dense bacterial layer on the spores and hyphae (Figs. 1A,C) of Gi. margarita. By contrast, few adhering cells of the A. brasilense partial EPS mutants were found associated with the surface of the fungal structures (Fig. 1B). Very rare bacterial cells of the EPS mutant of $R$. leguminosarum could be visualised on the hyphae of Gi. margarita (Fig. 1D).

\section{Attachment of Azospirillum brasilense to AM roots}

Attachment of the wild type and EPS defective A. brasilense strains to mycorrhizal carrot roots and to fungal hyphae of $G$. intraradices is summarized in Table II and shown in Figure 2. For both wild type strains, numerous bacteria were found on these biotic surfaces, either individually attached or densely associated to form thick layers (Fig. 2A,F). In the case of Sp7, bacteria often formed denser patches compared to strain 7030 . The same behaviour of the two wild type strains was also observed on the external hyphae of $G$. intraradices (Fig. 2B).

Mutants AB7001 and AB7002 are partially impaired in exopolysaccharide (EPS) production, whereas mutants 7030::Tn5-101 and 7030::Tn523 lack EPS completely and they are not stained by the fluorescent dye calcofluor (Table 1). Mutants AB7001 and AB7002 displayed a similar behaviour when tested for their ability to attach to

Table II

Adhesion of bacteria to root and fungal surfaces

\begin{tabular}{|c|c|c|c|c|}
\hline \multirow[t]{2}{*}{ Species } & \multirow[t]{2}{*}{ Strain } & \multirow[t]{2}{*}{ Phenotype } & \multicolumn{2}{|c|}{ Adhesion class* } \\
\hline & & & root & fungus \\
\hline \multirow[t]{6}{*}{ A. brasilense } & $\mathrm{Sp} 7$ & WT & 4 & 4 \\
\hline & 7030 & WT & 3 & 3 \\
\hline & AB7001 & $\mathrm{EPS}^{\mathrm{r}}$ & 2 & 2 \\
\hline & AB7002 & $\mathrm{EPS}^{\mathrm{r}}$ & 2 & 2 \\
\hline & $7030:: \operatorname{Tn} 5-23$ & EPS- & 1 & 1 \\
\hline & 7030::Tn5-101 & EPS- & 1 & 1 \\
\hline \multirow[t]{3}{*}{ R. leguminosarum } & B556 & WT & 3 & 3 \\
\hline & A507 & $\mathrm{EPS}^{\mathrm{r}}$ & 1 & 1 \\
\hline & A517 & EPS $^{r}$ & 1 & 1 \\
\hline
\end{tabular}

* Four classes of bacterial attachment were defined: class 1, no attachment; class 2, a few bacteria attached; class 3, bacteria evenly spread on the surface; class 4, dense coat of attached bacteria (Bianciotto et al. 1996). 
Fig. 1 - Association of wild-type and EPS mutant of $A$. brasilense (A, B) and $R$. leguminosarum $(\mathrm{C}, \mathrm{D})$ to germinated mycelium of Gi. margarita. A. brasilense wild type strain $\mathrm{Sp} 7$ (A) and R. leguminosarum wild-type strain B556 (C), forming a dense bacterial layer on a fungal hypha. By contrast, few bacterial cells were found (arrow) on the hypha when the EPS mutants AB7002 (B) and A517 (D) were used in the adhesion assays. (h) hypha, (n) fungal nuclei. Bars are $10 \mu \mathrm{m}$.

trasformed AM roots and to G. intraradices. The number of bacteria attached to the epidermal cells was greatly reduced compared to the wild type, and they rarely formed patches, although they could be still found as individual cells close to the root and fungal surfaces (Figs. 2C,D,E). The two calcofluor-minus mutants of $A$. brasilense displayed the same behaviour both on the mycorrhizal carrot roots and on $G$. intraradices.

When root samples were examined, some scattered bacterial cells were still found among the root hairs, but the number of bacterial cells in direct contact to the root surfaces was extremely low compared to the wild type (see Table II; Figs. $2 \mathrm{G}, \mathrm{H}, \mathrm{I})$.
A more detailed analysis of the attachment of wild type and EPS mutants to the root was performed by light and transmission electron microscopy (Fig. 3). At low magnification, both $\mathrm{Sp} 7$ and 7030 wild type bacteria could be seen in direct contact with the root surface or indirectly associated with it, being held together in a thick bacterial layer (Fig. 3A,C,D). Dividing bacteria were observed for both strains. The partial mutants adhered to a lesser extent to the plant cell surface (Fig. 3B). Figs. 3E and F show at higher magnification a patch of wild type Sp7 bacteria and an individual AB7002 partial EPS mutant attached to the epidermal cell wall. Bacterial patches formed by the wild type seemed to be held together by some amorphous extracellular material (Fig. 3E). 
Attachment of R. leguminosarum to AM roots When used in adhesion assays, wild type R. leguminosarum strain B556 was capable of forming a dense bacterial layer on AM carrot roots (Fig. 4 A) and on extraradical hyphae of $G$. intraradices (not shown). Two mutants of strain B556 impaired in EPS production were tested on carrot mycorrhizal roots, and the number of cells able to attach to both types of surfaces was extremely reduced compared to the wild type strain (See Table II; Fig. 4B).

The same bacterial strains tested for their adhesive properties on biological samples were also assayed for adhesion on an inert substrate such as quartz fibers. Whereas the wild type strains of both $A$. brasilense and $R$. leguminosarum showed good adhesion on this substrate, all mutant strains impaired in EPS production could not bind effectively (data not shown).

\section{DISCUSSION}

Microorganisms in natural environments live predominantly attached to solid surfaces. These sessile microbial communities, comprising either single or multiple species, are commonly referred to as biofilms and their formation has been studied in details on abiotic surfaces (Costerton et al., 1995).

Extracellular polysaccharides (EPS) play a major role in biofilm formation because they are involved in firm anchoring of bacteria to the substrate. In addition, EPS form the matrix that embeds the bacteria, where additional free bacteria can be entrapped (Costerton at al., 1995). Our results confirm that EPS are involved in the formation of root-associated biofilms by at least two important rhizosphere bacteria: A. brasilense and
$R$. leguminosarum. The formation of bacterial biofilms on the plant root surface may have a high significance, since biological activity of some PGPR depends on their ability to colonise the rhizosphere and to remain associated with the root (Lugtenberg and Dekkers 1999).

Similarly to the root, mycorrhizal fungi can release exudates that create a niche relatively rich in organic compounds compared to the bulk soil, the hyphosphere (Marschner 1995), where a specialised microbial community can be established (Andrade et al., 1997; Frey et al., 1997; Timonen et al., 1998). A synergistic activity has been observed between ectomycorrhizal fungi and their associated bacteria, for example in the degradation of toxic substrates (Sarand et al., 1999). Colonisation and adhesion of bacterial cells on the hyphal surface is likely to play an important role in the establishment of the hyphosphere community, and our results clearly demonstrate that EPS are involved in the process of biofilm formation on AM fungal structures.

Bacteria living in biofilms acquire specific properties, like the ability to survive much harsher environmental conditions. Increased resistance to drought, antibiotic stress are but some examples (Costerton et al., 1995; Palmer and White 1997). In addition, they express different metabolic pathways and different set of genes compared to planktonic cells (Prigent-Combaret et al., 1999). The achievement of a high cell density and the presence of an abundant matrix material that reduces diffusion are likely to influence gene regulation by diffusible signals involved in quorum-sensing. Such signals have been demonstrated within biofilms formed on freshwater rocks by McLean et al. (1997). Evidence of homoserine-lactone or analogous compounds has

Fig. 2 - Confocal micrograph of mycorrhizal carrot roots, showing adhesion of wild type and EPS mutant strains of Azospirillum brasilense.

A-E: Adhesion assay of the wild type strain Sp7 and its EPS mutant derivatives.

(A) Attachment of wild type strain Sp7 to the root surfaces; living bacteria are visible both on the epidermal cells and between root hairs as small yellow/green spots (arrows). (B) Association of wild-type strain Sp7 with external mycelium of Glomus intraradices. This strain forms a dense bacterial coat on the extraradical hypha (arrow). (C, D) Higher magnification of the interaction between the EPS ${ }^{\mathrm{r}}$ strains AB7002 (C) and AB7001 (D) and the root hairs. Some cells of the mutant strains were found among the root hairs, but few bacterial cells were in direct contact to the root surfaces (arrows). (E) A similar behaviour is found on the extraradical mycelium of G. intraradices. Few bacteria of strain AB7002 were found attached to the hyphae (arrow). F-I: Adhesion assay of the wild type strain 7030 and its EPS mutant derivatives.

(F) Bacterial biofilm of wild type strain 7030 on the root epidermal cells. (G-I) Extremely few cells of EPS ${ }^{-}$mutant strain 7030::Tn5-101 were found to associate with either the root hairs (arrow) $(\mathbf{G})$, the epidermal cells $(\mathbf{H})$ and fungal structures of $G$. intraradices (I). (e) epidermal cell, (rh) root hair, (f) fungal hypha, (s) fungal spore. Bars in A, B, F, H are $10 \mu \mathrm{m}$. Bars in C, D, $\mathrm{G}$ are $7 \mu \mathrm{m}$. Bars in $\mathrm{E}, \mathrm{I}$ are $12 \mu \mathrm{m}$. 

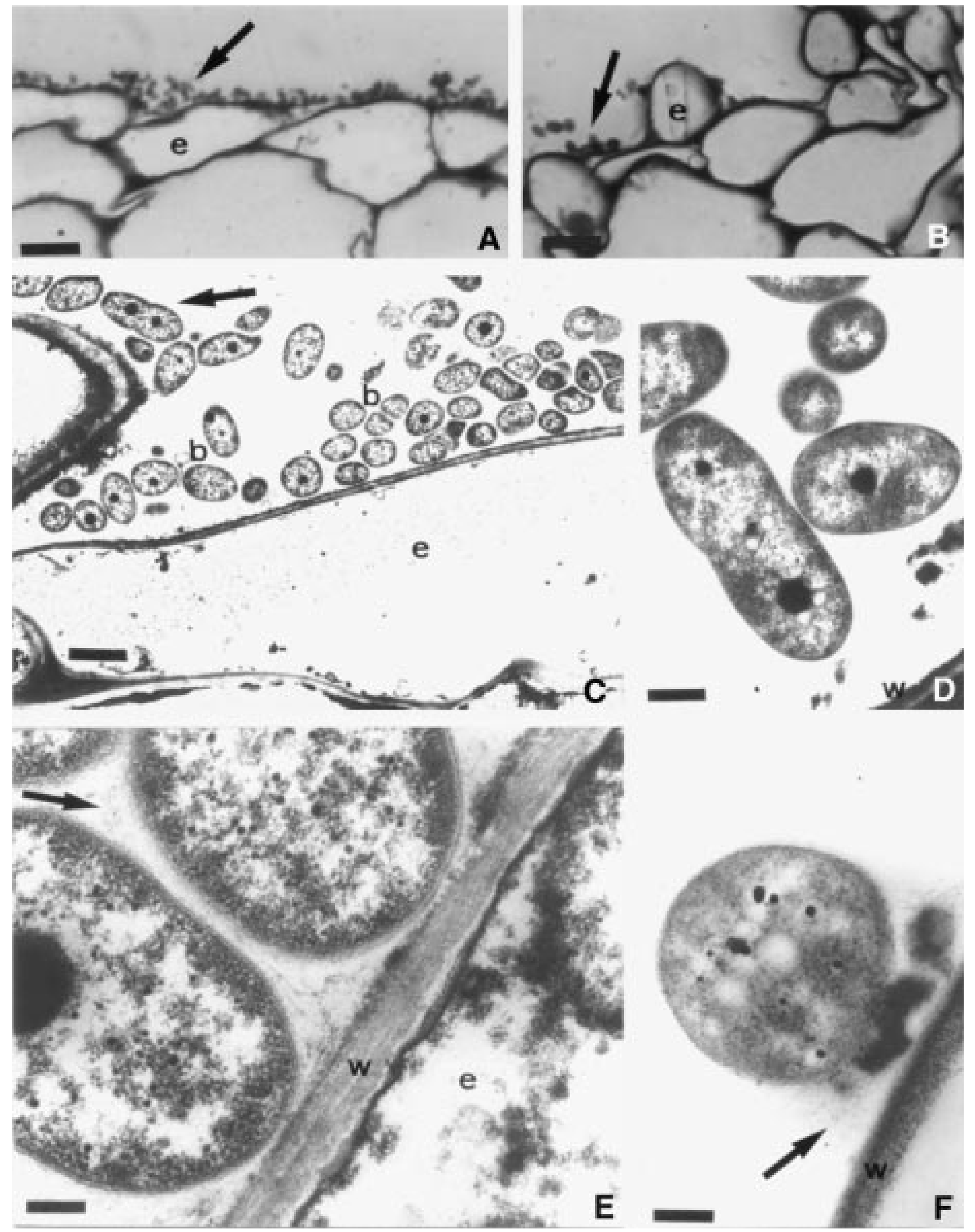
Fig. 4 - Confocal micrographs of mycorrhizal carrot roots after the adhesion assay with $R$. leguminosarum strains. (A) Bacterial clusters of the wild type strain B556 attached to root hairs; bacteria are all visible as small yellow/green spots. Some dead bacteria (stained in red) are visible. (B) Extremely few bacteria (arrow) were found attached to the fungal and root structures when adhesion assay were performed using either of the EPS mutants. In this case, the A517 strain was used. (e) epidermal cell, (rh) root hair, (f) fungal hypha. Bars are $7 \mathrm{~mm}$ in $\mathrm{A}$ and $10 \mathrm{~mm}$ in B.

been demonstrated in several rhizosphere bacteria (Cha et al., 1998), and it will be exciting to investigate whether specific functions may be induced in the rhizosphere and the hyphosphere biofilms.

Anchoring of rhizobacteria to AM fungal structures may have a special ecological significance because it may facilitate colonisation of new rhizospheres. In addition, our observations may also have a biotechnological meaning for the development of inocula based on selected mixtures of PGPRs and AM fungi. Since EPS play a general role in the protection of bacterial cells against desiccation (Ophir and Gutnick 1994), this trait could

be important in the production of inocula where its presence to form a stable fungus-bacterial association is essential.

\section{ACKNOWLEDGEMENTS}

We thank Jos Vanderleyden, Sara Moens and Allan Downie for providing the bacterial strains and for helpful discussion. We are thankful to Andrée Fortin (University of Montreal) for the transformed root system. Research was funded by the EU IMPACT2 project (BIO-CT96-0027).

Fig. 3 - Light and electron micrographs showing the attachment site of A. brasilense strains to the plant cell surface. (A) A bacterial biofilm of the wild type strain Sp7 on the root epidermal cells is visible (arrows) on a semi-thin section stained with toluidine-blu. (B) AB7002, impaired in EPS production, showed very little ability to associate with the root epidermis and only few bacteria are attached to the plant surface (arrow).

(C-E) Electron micrographs of the wild type strain Sp7 (C, E) and 7030 (D) on root surfaces. (C) Low magnification showing a dense layer of Sp7 bacteria on an epidermal cell Some bacteria adhere directly to the plant cell wall whereas some others are indirectly associated with it. Bacterial cell division can be observed (arrow). (D) A cluster of bacteria of the wild type strain 7030, showing the same phenomenon. (E) High magnification showing the attachment of two bacteria to the epidermal cell wall. Some extracellular material is visible between the bacteria (arrow). (E) Attachment of a single bacterial cell of the EPS mutant AB7002 to the plant cell wall; some extracellular material can be seen (arrow). (w) plant cell wall, (e) epidermal cell, (b) bacteria. Bars are 8. $\mu \mathrm{m}$ in $\mathrm{A}$ and $7 \mu \mathrm{m}$ in $\mathrm{B}$. Bar in $\mathrm{C}$ is $1 \mu \mathrm{m}$. Bar in $\mathrm{D}$ is $0.4 \mu \mathrm{m}$. Bar in $\mathrm{E}$ is $0.1 \mu \mathrm{m}$. Bar in $\mathrm{F}$ is $0.2 \mu \mathrm{m}$. 


\section{REFERENCES}

Andrade G., Mihara K.L., Linderman R.G., and Bethlenfalvay G.J.: Bacteria from rhizosphere and hyphosphere soils of different arbuscular-mycorrhizal fungi. Plant \& Soil 192, 71-79, 1997.

Barea J.M.: Mycorrhiza/bacteria interactions on plant growth promotion. In: Plant Growth-Promoting Rhizobacteria: present status and future prospects. (A. Ogoshi, K. Kobayashi, Y. Homma, F. Kodama, N. Kondo, and S. Akino, eds.), OECD Paris., pp. 150-158, 1997.

Bécard G., and Fortin J.A.: Early events of vesicular-arbuscular mycorrhiza formation on Ri T-DNA transformed roots. New Phytol. 108, 211-218, 1988.

Bethlenfalvay G.J., and Lindermann R.G., eds.: Mycorrhizae in Sustainable Agriculture. ASA Special publication N. 54 Madison, Wisconsin, 1992

Bianciotto V., Minerdi D., Perotto S., and Bonfante P.: Cellular interactions between arbuscular mycorrhizal fungi and rhizosphere bacteria. Protoplasma 193, 123-131, 1996.

Boddey R.M., Urquiaga S., Reis V., and Doberreiner J.: Biological nitrogen fixation associated with sugar cane. Plant \& Soil 137, 111-117, 1991.

Burdman S., Okon Y., and Jurkevitch E.: Surface characteristics of Azospirillum brasilense in relation to cell aggregation and attachment to plant roots. Critical Rev. Microbiol. 26, 91 $110,2000$.

Chabot S., Bécard G., Piché Y.: Life cycle of Glomu intraradix in root-organ culture. Mycologia 84, 315-321, 1992

Cha C., Gao P., Chen Y.C., Shaw P.D., Farrand S.K.: Produc tion of acyl-homoserine lactone quorum-sensing signals by gram-negative plant-associated bacteria. Mol. Plant Microbe Interact. 11, 1119-29, 1998.

Costerton J.W., Lewandowski Z., Caldwell D.E., Korber D.R. and Lappin-Scott H.M.: Microbial biofilms. Annu. Rev. Microbiol. 49, 711-45, 1995

Croes C., Moens S., Van Bastelaere E., Vanderleyden J., and Michielis K.: The polar flagellum mediates Azospirillum brasilense adsorption to wheat roots. J. Gen. Microbiol. 139 , 2261-2269, 1993

Défago G., and Keel C.: Pseudomonads as biocontrol agents of diseases caused by soilborne pathogens. In: Benefits and Risk of introducing biocontrol agents. (H. M. T. Hokkanen, and J. M. Lynch, eds.) University Press, Cambridge, pp. 137-148, 1995.

Dufrêne Y.F., Vermeiren H., Vanderleyden J., and Rouxhet P. Direct evidence for the involvement of extracellular proteins in the adhesion of Azospirillum brasilense. Microbiology 142 , $855-865,1996$

Frey P., Frey-Klett P., Garbaye J., Berge O., and Haeulin T. Metabolic and genotypic fingerprinting of fluorescent pseudomonads associated with the Douglas Fir-Laccaria bicolor mycorrhizosphere. Appl. Environ. Microbiol. 63, 1852 1860, 1997.
Garbaye J.: Helper bacteria: a new dimension to the mycorrhizal symbiosis. New Phytol. 128, 197-209, 1994.

Gerdemann J.W.: Spores of mycorrhizal Endogone species extracted from soil by wet sieving and decanting. Trans. Brit. Mycol. Soc. 46, 235-244, 1963.

Kloepper J.W., Zablotowick R.M., Tipping E.M., and Lifshitz R.: Plant growth promotion mediated by bacterial rhizosphere colonizers. In: The rhizosphere and plant growth. (D. L. Keister, and P. B. Cregan, eds.) Kluwer Academic Press, Dordrecht, pp. 315-326, 1991.

Lugtenberg B.J.J., de Weger L.A., and Bennett J.W.: Microbial stimulation of plant growth and protection from disease. Curr. Opin. Microbiol. 2, 457-464, 1991.

Lugtenberg B.J.J., and Dekkers L.C.: What makes Pseudomonas bacteria rhizosphere competent? Environ. Microbiol. 1 , 9-13, 1999.

Lynch J.M.: The Rhizosphere, John Wiley \& Sons, New York, 1990.

Marschner H.: Mineral nutrition of higher plants, $2^{\text {nd }}$ edition, Academic Press, London, 1995.

McLean R.J.C., Whiteley M., Stickler D.J., and Fuqua W.C.: Evidence of autoinducer activity in naturally occurring biofilms. FEMS Microbiol Lett. 154, 259-263, 1997.

Michielis K., Vanderleyden J., Van Gool A.P., and Signer E.R. Isolation and characterization of Azospirillum brasilense loci that correct Rhizobium meliloti exoB and exoC mutations. J. Bacteriol. 170, 5401-5404, 1988

Michielis K., Verreth C., and Vanderleyden J.: Azospirillum lipoferum and Azospirillum brasilense surface polysaccharide mutants that are affected in flocculation. J. Appl. Bacteriol. $69,705-711,1990$.

Michielis K., Croes C., and Vanderleyden J.: Two differen modes of attachment of Azospirillum brasilense Sp7 to wheat roots. J. Gen. Microbiol. 137, 2241-2246, 1991

Moore P.J., Swords M.M., Lynch M.A., and Staehelin L.A.: Spatial organization of the assembly pathways of glycoproteins and complex polysaccharides in the Golgi apparatus of plants. J. Cell Biol. 112, 589-602, 1991.

Nurmiaho-Lassila E.L., Timonen S., Haahtela K., and Sen R.: Bacterial colonization patterns of intact Pinus sylvestris mycorrhizospheres in dry pine forest soil: an electron microscopy study. Can. J. Microbiol. 43, 1017-1035, 1997.

Ophir T., and Gutnick D.L.: A role of exopolysaccharides in the protection of microorganisms from desiccation. Appl. Environ. Microbiol. 60, 740-745, 1994

Palmer R.J., and White D.C.: Developmental biology of biofilms: implications for treatment and control. Trends in Microbiology 5, 435-440, 1997.

Prigent-Combaret C., Vidal O., Dorel C., and Lejeune P.: Abiotic surface sensing and biofilm-dependent regulation of gene expression in Escherichia coli. J. Bacteriol. 181, 5993-6002, 1999 
Sarand I., Timonen S., Koivula T., Haahtela K., Sen R., and Romantschuk M.: Biodegradation of m-toluate by Scots pine, mycorrhizal fungi and the associated bacteria. Journal of Applied Microbiology 86, 817-826, 1999.

Sindhu S.S., Brewin N.J., and Kannenberg E.L.: Immunochemical analysis of lipopolysaccharides form free living and endosymbiotic forms of Rhizobium leguminosarum. J. Bacteriol. 172: 1804-1813, 1990.

Smit G., Swart S., Lugtenberg B.J., and Kijne J.W.: Molecular mechanisms of attachment of Rhizobium bacteria to plant roots. Mol. Microbiol. 6, 2897-903, 1992.

Smith S.E., and Read D.J.. Mycorrhizal symbiosis, Academic Press, San Diego, 1997.

Tarrand J.J., Krieg N.R., and Döbereiner J. A: Taxonomic study of the Spirillum lipoferum group, with description of a new genus, Azospirillum gen.nov. and two species A. lipoferum and A. brasilense. Can. J. Microbiol. 24, 967-980, 1978.
Timonen S., Jørgensen K.S., Haahtela K., and Sen R.: Bacterial community structure at defined locations of Pinus sylvestris - Suillus bovinus and Pinus sylvestris - Paxillus involutus mycorrhizospheres in dry pine forest humus and nursery peat. Can. J. Microbiol. 44, 499-513, 1998.

Vande Broek A., and Vanderleyden J.: The role of bacterial motility, chemotaxis and attachment in bacteria-plant interactions. Mol. Plant Microbe Interact. 8, 800-810, 1995.

Weller D.M.: Biological control of soilborne plant pathogens in the rhizosphere with bacteria. Annu. Rev. Phytopathol. 26, 379-407, 1988

Zorreguieta A., Finnie C., and Downie J.A.: Extracellular glycanases of Rhizobium leguminosarum are activated on the cell surface by an exopolysaccharide-related component. J. Bacteriol. 182, 1304-1312, 2000 